\title{
India's Security Partnership with Singapore
}

India and Singapore have developed a bilateral security and economic partnership that has a central position in India's growing strategic engagement in Southeast Asia. Having sought strategic engagement with India for many decades, Singapore has now successfully positioned itself as India's leading political partner and economic gateway to the region. The two have also actively pursued close defence ties, including frequent joint training and the assumption of an active regional maritime security role by India. The recent decision by India to allow the Singapore air force and army to operate long term training facilities on Indian territory also represents a significant development in Indian strategic practice.

This article will examine these developments and consider to what extent the relationship should be seen as a desire to balance China's growing economic and political dominance of the region and to what extent it reflects a return to a "natural" strategic sphere for India stretching from Aden to Singapore and beyond into East Asia. While India has in recent years been developing relationships with a number of Asia-Pacific states, Singapore, despite its small size, may well act as a pivot to the future development of India's security role throughout the region.

India's hesitant strategic role in Southeast Asia

Although, as this article will argue, the current security engagement between India and Singapore to a significant degree is derived from a natural strategic affinity, India has not always pursued an active role in the region.

The institutional links between Singapore and India underlying the renewed relationship are as old as Singapore itself. Singapore was founded by the British East India Company and for almost the first 50 years of its settlement was under the direct administration of British India. To a great extent Singapore inherited its political, legal and administrative systems from the Raj - it was under the authority of the Indian legislative council, the jurisdiction of the Supreme Court of Calcutta and its civil service was established by the Indian civil service. Even after Singapore was placed under 
separate colonial control, it was assumed that British India would be primarily responsible for its security. This reflected not only the availability of Indian colonial forces, but also a broadly held acceptance prior to World War II that the "natural" strategic sphere of British India covered the Indian Ocean, running from Aden to Singapore and beyond. Leading strategic thinkers from Lord Curzon to K.M.Panikkar recognized the strategic importance of Singapore to India as the eastern anchor of India's maritime security and that India - whether British-controlled or independent would be a principal security provider to Singapore (Curzon 1909; Panikkar 1943: 100-1). ${ }^{1}$ The importance of Singapore as the eastern anchor to India's maritime security was played out when the fall of Singapore to the Japanese in February 1942 (involving the surrender of some 40,000 Indian troops) was followed by the capture of the Andaman Islands in the Bay of Bengal, followed by the evacuation of the British fleet to Africa, exposing India's entire eastern seaboard to invasion. The Japanese were for various reasons unwilling or unable to properly exploit their position.

The granting of independence to India in 1947 and the subsequent decolonization of Southeast Asia led to a significant discontinuity in India's perception of the region. The Nehruvian political philosophy that formed the foundation of Indian strategic doctrine largely eschewed a direct security role for India outside of South Asia. India did not recognize the legitimacy of colonialera security linkages between South and Southeast Asia and instead saw its interests as limited to (largely ineffective) efforts to minimize the intrusion of other major powers into Southeast Asia. Nehru gave relations with Southeast Asia a particularly low priority and in the Indian diplomatic service all postings in Southeast Asia were classified as "category C", the least desirable and important in the diplomatic service hierarchy. At a 1961 meeting in New Delhi between Nehru and the Indian ambassadors to Southeast Asia, when one senior diplomat suggested that India should seek to nurture close relations with Southeast Asian Nehru reportedly cut the ambassador short, declaring: "Do you gentlemen wish to become friendly with Coca Cola governments?" This reportedly ended any further discussion on the subject (Dixit 2004: 12). However, while Nehru 
resented the growing U.S. strategic and cultural influence in Southeast Asia, he was also unwilling to take active steps to counter it through cultivating India's own relationship in the region. As a result, India abdicated any leadership role in the area and only really sought to exert its influence in negative terms, such as its emphatic rejection of SEATO (Brecher 1968: 315). Although Nehru's Fabian socialist disdain for the strategic concerns of Southeast Asian states was progressively moderated under Indira Gandhi and successive Indian leaders, the basic temper of the relationship had been established and would to some extent remain until the early 1990 s.

Despite India's abdication of any strategic responsibility in the region and its tarnished reputation following its defeat at the hands of China in 1962, the Singaporeans continued to recognise a legitimate role for India as a regional security provider In what has been called Singapore's "survival phase" in the years following independence, Singapore saw itself as being in a precarious strategic position, concerned not only with the prospect of Communist Chinesesupported internal subversion but also with external threats posed by Indonesia and a potentially revanchist Malaysia. Singapore saw India as potentially helping to maintain its new-found sovereignty against infringements by China as well as its large neighbours. During the 1960s, Singapore made several attempts to develop a security relationship with India. However, while India was willing to provide diplomatic assistance to the newly independent Singapore in developing international relations, it showed little interest in acting as a security provider (Lee 2000: 450). ${ }^{2}$ India wished to avoid any suggestion of it joining any anti-China bloc and its desire to minimize international support for Pakistan also made it sensitive towards being seen as assisting Singapore against its Muslim neighbours.

Soon after the establishment of diplomatic relations between an independent Singapore and India in 1965, Lee Kuan Yew made a request to Indian Prime Minister Shastri for Indian assistance in training the newly-established Singapore army. The Indians declined to even respond to the request, presumably so as not to be seen as taking sides against Malaysia (Lee 2000: 30-1). ${ }^{3}$ (The 
United States, Britain, Egypt also reportedly declined Singapore requests for assistance in military training, forcing Singapore to turn to Israel for military advisors.) In May 1968, following the announcement of the withdrawal of the British navy from Singapore, Lee again unsuccessfully sought to encourage an Indian military presence in Singapore, proposing to Indira Gandhi that the Indian navy should take over the Royal Navy's regional security role, including making use of Singaporean naval dockyard facilities for the building and repair of ships (Suryanarayan 2008). When, during a visit to India in 1970, Lee asked Indira Gandhi whether India intended to extend its naval influence into Southeast Asia, the Indian Foreign Minister Swaran Singh responded that India's greater interest was in keeping its western sea lanes open (Lee 2000: 452).

The Singaporeans also unsuccessfully sought to persuade India to assume a broad regional security role primarily but not always to counterbalance China. Following the first Chinese Lop Nur nuclear test in October 1964 - even before Singapore's formal independence - the ever quotable Lee Kuan Yew reportedly suggested to visiting Indian dignitaries and journalists that India should also explode a nuclear bomb, "at least for the sake of Southeast Asia, even if she wanted to throw it into the sea later" (Dutt 1984: 256). Through the late 1960's, Singapore's leaders were concerned about the possibility of a regional power vacuum following the British withdrawal and the likely reduction in the US military presence following a wind-down of the Vietnam war. In 1966, Lee proposed that India should adopt an "Asian Monroe Doctrine" to prevent "poaching" in Asia. Lee added that India was the ideal candidate to fulfill such as role because it conducted its foreign policy "on a basis of equality and not on a basis of power relations"(Straits Times, 3 September 1966). He told Indian Prime Minister Indira Gandhi during his 1966 visit to New Delhi that India should consider taking a leading role in multilateral security arrangements for Asia (Dutt 1984: 277-8). The Indians however again declined to make any official response to Lee's proposal. Singapore also reportedly tried to encourage India to join ASEAN upon its formation in 1967, perhaps with a view to finding a balance with large states within that grouping. However, other ASEAN states were not in favour of 
India's inclusion (possibly for the same reason) and India also remained suspicious of a possible security dimension to ASEAN (Sridharan 1996: 49).

India's opposition to involvement in any regional security mechanism puzzled the Singaporeans and others in Southeast $\mathrm{Asia}^{4}$, particularly in light of shared perceptions of a threatfrom China. To Southeast Asians, India's persistent downplaying of any idea of a power vacuum and statements about the uselessness of military alliances seemed callous, incredible and unrealistic (Sridharan 2001: 74). Lee reportedly told friends after talks with Indian officials that India was "living in a dream world" (Sridharan 1996: 40). The Indians however opposed security alliances or treaties a priori as part of Nehruvian strategic doctrine. Further, there were important differences in perceptions of the ideological or military threat posed by China - the Singaporeans saw Chinese expansionism primarily as an issue of communist subversion, while the Indians saw Chinese expansionism not primarily as an ideological issue but as a distortion of Chinese nationalism. The Indians also saw themselves as hardly capable of providing for their own security, let alone acting as a regional security provider. As the Indian External Affairs Minister, B.R.Bhagat argued in the Indian parliament in April 1968: "If there was a defence agreement [with Southeast Asia] it would only mean India committing her manpower to the defence of areas which is beyond our capacity at present... If we dispersed our efforts and took on responsibilities that we are not capable of shouldering, it would not only weaken our own defence but would create a false sense of security and might even provoke a greater tension in the area." Rather than working directly with Southeast Asian states to improve their security, India confined its efforts to the half-hearted endorsement of proposals for major power security guarantees of the region, such as the vague and unworkable Soviet collective regional security proposal made in 1969.

The Singaporeans soon began to conclude that India did not have the material or moral wherewithal to extend its influence into Southeast Asia. Lee observed what he called a "gradual run-down of the country." By the end of the 1960s, India was moving towards a security 
relationship with the Soviet Union, formalized in 1971, in which India effectively gained a Soviet security guarantee against China. As a result, India largely lost whatever interest it may have had in the security of Southeast Asia, that is, apart from a keen interest in limiting the influence of the United States and China in Indochina. During this period, the balance of Singapore's strategic and economic interests also shifted away from the Indian Ocean and towards the Asia-Pacific and the United States (see generally, Chew 2008).

It was Indira Gandhi's refusal to oppose what Singaporeans saw as aggression by the Soviets and their proxies in the region that brought Singapore - India relations to their lowest point. Through the 1970s, New Delhi's burgeoning relationships with Moscow and its regional ally, Vietnam, were viewed with a significant degree of suspicion which came to a head with the Vietnamese invasion of Cambodia. In a major diplomatic misstep, in June 1980 the Gandhi government cancelled planned meetings with ASEAN ministers to discuss India's elevation as a full dialogue partner of ASEAN (a move which India had initiated several years earlier). Days later, India officially recognized the Vietnam-installed Cambodian government, becoming the first noncommunist state to recognize the regime. India's action was interpreted as proof of it toeing the Moscow-Hanoi line. The Singaporeans, in particular, took a hardline stand on the Vietnamese actions, seeing it as a major test of the principle of sovereignty of small states, even if run by a despised regime such as the Khmer Rouge. Singapore Foreign Minister S.Rajaratnam observed that India's recognition of the Vietnam-backed Heng Samrin regime would "amount to endorsing aggression and forcible installation of puppet regimes" (Statesman, 16 June 1980). Lee Kuan Yew was even advised at one stage to break off diplomatic relations with India over the issue (Suryanarayan 2008). For their part, Indian policy-makers viewed Singapore's stance on Cambodia as not based on real fears of Vietnamese expansionism, but that it was merely playing an anti-Soviet card to curry favour with the United States. India's continuing support for Vietnam and its failure to condemn the Soviet occupation of Afghanistan would bedevil political relations between India and 
Singapore and other ASEAN states for the remainder of the 1980s. Nevertheless direct engagement between the Indian and Singapore armed forces which had been gradually developing through the 1970s continued through the political disagreements of the 1980s, including high level visits by Indian and Singapore officers, the provision of training to Singapore by Indian air force instructors (in both India and Singapore), and the supply by Singapore of missile gunboats to India.

The collapse of the Soviet Union in 1991 quickly led to a major reassessment by India of its political and economic relationship with Southeast Asia. In 1992, following a major balance of payments crisis, India launched its "Look East" policy, initially seeking to convince the Southeast Asians that India was now a welcoming environment for foreign investors. With the Cambodian and Afghanistan issues resolved, the Indians were also in a position to pitch for a security engagement with ASEAN, when Indian Prime Minister Rao declared in Singapore in 1994 that: "India would like to be part of the evolving security framework in the region to assuage doubts about arising from its potential military might as to contribute to the security edifice that was being crafted by the Asia-Pacific powers" (Sridharan 1996: 178). Singapore, unlike Malaysia and Indonesia, was unencumbered by Islamic political loyalties and represented an attractive political and economic gateway for India into ASEAN.

Singapore, which itself was undergoing somewhat of a foreign policy reorientation, responded to India's new policy with enthusiasm. Despite fears in the early 1990s that a superpower withdrawal from the region might lead to unhealthy rivalry between Japan, China and India, the Singaporeans had concluded by 1993 that India's strategic presence in Southeast Asia would, as they said, "help stabilize the region by counterbalancing the other political heavyweights"(Sridharan 2003: 21). ${ }^{5}$ Singapore was concerned not only about a more assertive China (which in 1992 had claimed much of the South China Sea as Chinese territory), but also by the modernization of the Malaysian and Indonesian armed forces and fears of the possible formation of a Kuala Lumpa-Jakarta political axis directed against it (Huxley 2000: 46). ${ }^{6}$ At about the same time, 
the Singapore government also concluded that for its relatively mature economy to develop further in spite of its severely limited size and resources, it needed to create an "external economy" within the region as a "second wing" to its onshore economy (Mahizhnan 1994). India, with its large labour force and relatively undeveloped markets, was identified as a key target for the development of an external economy for Singapore.

Singapore quickly positioned itself as India's de facto regional sponsor and became central to India's multilateral engagement in Southeast Asia. With Singapore's political support, India was soon elevated to be a full ASEAN dialogue partner in December 1995 (slightly prior to China) and following Singapore's hard lobbying of reluctant ASEAN members, India joined the ASEAN Regional Forum in 1996. India's entry into the ARF reportedly involved a significant diplomatic effort by Singapore to overcome fears of importing the India-Pakistan dispute into the forum (Sridharan 2001: 76). When India was refused membership in the ASEAN plus 3 (China, Japan and South Korea) grouping in 2000, Singapore successfully lobbied for a separate India-ASEAN summit, which was held in November 2002 (Sridharan 2003: 28-9)..$^{7}$ In 2005, Singapore (along with Japan and others) supported the inclusion of India in the first East Asian Summit, with Lee arguing that it "would be a useful balance to China's heft" (Lee 2005). Unsurprisingly, Lee also supported the inclusion of India in any future Asian Economic Community, arguing that it would held "expand the market" and lead to "more specialization and division of labour" (Suryanarayana 2005). ${ }^{8}$ Despite these developments, it is clear that India, as a late starter in the process of economic and political engagement with the region, has not approached the depth of the relationship that China has with most ASEAN states.

While acting as India's regional sponsor, Singapore also worked hard to develop the bilateral relationship. Despite skepticism among many ASEAN partners about the ability of India to deliver economic development comparable to China, the Singaporeans have showed considerable tolerance of and patience with Indian systemic problems, seeking in many cases to bypass New Delhi and work 
directly with Indian state authorities, while nudging the centre towards economic and institutional reform (Straits Times, 20 January 2000).

\section{The economic partnership}

Inevitably, economics plays a primary role in most of Singapore's bilateral relationships, and Singapore's relationship with India is no different. Although Singapore plays an important role as an economic gateway between China and Southeast Asia, in many ways India represents a greater opportunity. In contrast to China, which has the benefit of longstanding direct trading links with many Southeast Asian economies (including through the large Chinese ethnic communities in many states), India's direct economic ties with the region are much less established. As well as acting as India's gateway to Southeast Asia, the Singaporeans also believe that they can become a trade and financial intermediary between India and China (Yeo 2005). More generally, they believe they can assist in India's development as an "economic balancer" to China. As Singapore Prime Minister Goh Chok Tong explained in 2004: "We see Singapore as being lifted by two economies. I visualize ASEAN as a fuselage of a jumbo plane with China as one wing, and India the other wing. If both wings take off, ASEAN as the fuselage will also be lifted. Singapore is part of this fuselage" (Ong 2004).

Singapore has aggressively pursued economic ties with India since the opening of the Indian economy and the announcement of its Look East policy in Singapore in the early 1990s. Singapore has now become the largest investor in India among ASEAN states and in 2006/07 the 3rd largest foreign investor in India overall. In 2006, cumulative investment stood at US\$3 billion, much of it in the infrastructure sector, including ports and roads. Bilateral trade has grown from US\$2.34 billion in 2000/01 to US\$11.49 billion in 2006/07 (with the balance of trade in India's favour). By some (perhaps optimistic) estimates it could reach US\$50 billion by 2010 (Indian Business Insight, 30 June 2005). Nevertheless, Singapore-India bilateral trade is a fraction of Singapore-China trade and is likely to remain so for some time. 
In June 2005, India and Singapore signed an extremely broad-ranging Comprehensive Economic Cooperation Agreement, the first such arrangement India has entered into with a developed country. The CECA is unusually comprehensive, covering not just trade in goods, but also services (including financial services), investment and tax. It provides for significant tariff reductions on goods covering approximately $80 \%$ of Singapore's then exports to India and provides for Indian exports to Singapore tariff free - thereby promoting Singapore's role as a logistics hub for the export of Indian goods to Asia and the United States. However, the most significant aspects of the CECA are its treatment of services, investment and tax. It provides for removal of many restrictions on services, something of particular significance for India with its large number of well-trained English speakers. The CECA also extends to financial services, giving specified Singaporean banks unrestricted access to the Indian market (and Indian banks to the Singaporean market) and provides special arrangements for Singaporean companies (and in particular the Singapore state-controlled investment companies, Temasek and GIC) to invest in India. The significance of the tax treaty arrangements should also not be underestimated, providing special concessions to Singapore companies which place it on par with Mauritius and Cyprus, historically the two primary gateways for foreign investment into India. As a result of the CECA, more than 2,800 Indian-owned companies now operate out of Singapore (Indiapost 2008). Put together, the CECA gives Singapore a gateway role with respect to India - particularly in relation to financial services and investment - that it could never realistically hope to achieve with China. ${ }^{9}$ The China-Singapore Free Trade Agreement, which signed only in October 2008 , is significantly more limited in scope. The Singaporeans certainly have high hopes for the CECA as a key element in India's regional economic integration and Singapore Prime Minister Goh Chok Tong suggested that the agreement would eventually lead to an Asian Economic Community linking South Asia, Southeast Asia and Northeast Asia (Kumar 2006).

The India-Singapore economic agreement also stands in contrast with the slower progress on India's other regional free trade arrangements. Whereas the clear complementarities in the India 
and Singapore economies have assisted in the creation of economic links, the negotiation of free trading arrangements including other ASEAN states is hampered by greater competition in low- end manufacturing and agriculture. The multilateral ASEAN-India Free Trade Agreement signed in August 2009 will substantially reduce tariffs on most manufactured items traded with ASEAN with the exception of important sectors such as textiles, chemicals, automobiles and steel. The deal will be largely confined to manufactured goods, allowing India to continue to protect agriculture, while ASEAN states will continue to protect their services sectors. If anything, the limited scope of the India-ASEAN FTA may well reinforce Singapore's role as India's economic gateway in Southeast Asia.

\section{The new security partnership}

The development of bilateral security links between Singapore and India since the end of the Cold War have paralleled - and in some respects preceded - the growth in the economic relationship. Although India's Look East Policy was primarily focused on economic engagement with Southeast Asia, it also had a significant security element. Indian Prime Minister Rao raised the prospect of substantial defence cooperation with Singapore Prime Minister Goh Chok Tong as early as September 1992 (Muni 2003: 44). In 1994 the Indian and Singapore navies agreed on the terms of cooperation on the protection of sea lanes in the eastern Indian Ocean, including the training of Singapore personnel in anti-submarine warfare (Sengupta 1998). India and Singapore have held annual bilateral naval exercises since 1993 and since 1995 Singapore has participated in the biennial MILAN naval "gathering" hosted by India in the Andaman Islands.

From around the turn of the century, in what has been called the second phase of its Look East Policy, India has become more proactive in developing the relationship. In October 2003 following India's request, Singapore and India entered into a defence cooperation agreement providing for comprehensive annual defense policy dialogues between defense secretaries, joint exercises and intelligence sharing and cooperation in defense technology. This facilitated extensive and broad-based defence cooperation. Intelligence cooperation was formalized through the 
establishment in 2003 of a Joint Working Group for Intelligence Cooperation on Combating Terrorism and Transnational Crime and cooperation in defence technology was formalized through the establishment in 2006 of a Defence Technology Steering Committee. India has become the largest aggregate recipient of Singaporean arms exports and further major deals may be in the pipeline. ${ }^{10}$

In addition to extensive joint maritime exercises discussed below, beginning in 2004 the Indian and Singapore air forces have conducted annual exercises (generally hosted by India, but hosted by Singapore in 2006). Beginning in 2005 India has hosted the annual "Agni Warrior" artillery and "Bold Kurukshetra" armoured exercises (which by 2007 included joint planning of brigade-level armoured operations). From 2004, Singapore had been granted access to Indian facilities to conduct its own air and army training. ${ }^{11}$ However, the security relationship was taken to a new level when, in October 2007, India agreed to upgrade Singapore's training facilities in India, including allowing long term use of the Indian Kalaikunda air base (near Kolkata) by the Singapore Air Force. In August 2008, India also agreed to the stationing of a small number of Singapore army personnel and artillery and armoured vehicles at its Babina and Deololli firing ranges for an initial 5 year term.

The operation of training facilities on foreign soil is certainly nothing new for Singapore which, due to severe constraints on domestic land and airspace, has for many decades had numerous overseas training establishments for its air force, army and navy. ${ }^{12}$ In fact, the Singaporeans, as ever, have made a virtue out of necessity. In what has been called a "second wing" to its defence (Singh 1999: 301), Singapore has used its overseas establishments to give its armed forces (and particularly its air force) strategic depth as well as to develop closer relationships with its informal allies. It has been speculated that the growing relationship with India may also eventually replace Singapore's existing training arrangements with Taiwan which, naturally, represent an ongoing irritant to Singapore-China relations (Jane's Sentinel Southeast Asia 2008: 585). 
The long term use of Indian territory by foreign military defense forces does however represent a major shift in Indian policy. Since 1947, India has as a matter of policy been opposed to any foreign military bases in Asia. India has fiercely opposed any foreign military bases on its territory and has until recently refrained from establishing its own military bases elsewhere. ${ }^{13}$ In the early 1960s, in the wake of the Sino-Indian war, the Indians refused to allow U.S. forces to be based in India to assist in its defense, and in the early 1970s resisted pressure from the Soviets to be granted limited naval basing rights to support the Soviet Indian Ocean fleet. It appears that these "sacred cows" of Indian politics are quietly dying - at least so far as Singapore is concerned - as the announcement of these arrangements seems to have created relatively little political stir in India.

\section{Cooperation in maritime security}

Given the position of Singapore at the head of the Malacca Strait, between the South China Sea and the Indian Ocean, maritime security will inevitably be at the heart of any security relationship between India and Singapore.

Since the end of the Cold War, the Singapore and Indian navies have exercised together frequently, and the tempo of joint training has increased in recent years. Singapore and India have held annual bilateral naval exercises since 1993 (which later became known as the SIMBEX exercises), making Singapore India's longest running naval exercise partner in Asia and India's only regular bilateral exercise partner in the region. The exercises started primarily with an antisubmarine focus and over the years have expanded in both size and scope to include maritime interdiction, air defense and gunnery and, according to the Indian government, a very substantive measure of interoperability has now been achieved. While most joint exercises have been held in the Bay of Bengal, more recently, in 2005 and 2007, exercises have also been held in the South China Sea (which, according to the Commanding Officer of the Indian Navy's Eastern Fleet, was "was not a signal to be given to somebody." (Straits Times, 17 November 2005)). The Indian navy also provided Singapore with training onboard Indian submarines, as well as providing the Singapore navy with 
access to Indian naval facilities and firing ranges (Naidu 2004: 339). In 2007, the annual Malabar exercises with the United States were expanded to also include Singapore, Japan and Australia. This resulted in significant domestic criticism in India, forcing the Indian Defence Minister A.K. Antony to deny that it signalled any new military alignment.

India has overcome its longstanding reticence towards acting as a security provider in Southeast Asia and adopted a cooperative approach towards maritime security in the region. In June 2000, Indian Foreign Minister Jaswant Singh commented in Singapore that: "An uninterrupted access to the Malacca Strait and the South China Sea, vital for the economies of the ASEAN region and India, needs to be ensured... India has never encroached on the strategic space of ASEAN while still contributing to stability" (Straits Times, 15 November 2000: 17). Shortly after, the Indians announced the establishment of a Far Eastern Naval Command, based in the Andaman Islands in the Bay of Bengal, involving the development of major new naval basing and repair facilities, due to be completed in 2012. The expansion of India's naval role in the area, supported by the construction of the new port facilities, has been strongly encouraged by the United States, which, according to one report, also offered to partly fund their construction (Maitra 2005).

In the wake of September 2001, India significantly stepped up its presence in the Malacca Strait, providing naval escorts of commercial traffic in coordination with the United States as part of Operation Enduring Freedom. Singapore supported India's participation in the operation (including hosting Indian naval vessels), while Malaysia and Indonesia were "consulted." (Malaysia and Indonesia have much greater sensitivity towards a foreign naval presence inside the strait due to the territorial nature of the waterway.) Initial reservations about an Indian role in the Malacca Strait area appear to have subsided somewhat and India has been careful to ensure that its presence in the area is seen as "non-intrusive, cooperative and benign" by the littoral states (Straits Times, 15 November 2000: 17). The assistance provided by an Indian naval task force to Indonesia following the tsunami in December 2004 certainly reinforced such a role. In June 2006 Singapore Defence 
Minister Teo Chee Hean stated that Singapore "welcomed" India's offer to contribute to the security of the Malacca Strait, although "it should be done in a way that littoral states are comfortable with" (Bernama 2006).

While a cooperative role for the Indian navy in the region west of the Malacca Strait is now more or less accepted within Southeast Asia, ${ }^{14}$ the extension of Indian naval power north into the South China Sea remains more controversial. India has been quietly extending its naval power into the South China Sea through regular visits and joint exercises in what has been called "deliberate, significant and maintained long range Indian naval appearances" (Scott 2007: 33). The Indians began implementing a detailed plan to expand the horizons of Indian naval diplomacy (Joseph 2000) in late 2000, when Indian warships made an extended visit to the South China Sea including port visits to Vietnam, China and the Philippines, and as far north as South Korea and Japan. During 2004, the Indian navy made three separate deployments into South China Sea as part of "Presencecum-Surveillance Missions" in the Malacca Strait, and in 2005 the Indian aircraft carrier INS Vikraat and task force made a first ever visit to Singapore, Malayasia and Jakarta, Indonesia. The Indian navy has conducted multi-ship deployments to the region in each year since then, whether as unilateral exercises, or as part of bilateral exercises with Singapore, Japan, and the United States. The Indian navy however continues to formally identify the South China Sea as a "secondary area" of interest in its 2007 Maritime Military Strategy, while Malacca Strait is identified as a "primary area" of interest.

Mohan argues that India, by virtue of its growing economic and military power, will become a significant naval power in the Western Pacific and that Singapore will act as the "fulcrum" of India's extended reach into the Pacific (Mohan 2009). Some argue that without port facilities in the South China Sea, the projection of Indian naval power north of the Malacca Strait will be of limited credibility. Requests by India to use Vietnam's Cam Ranh Bay naval base, reportedly made in 1990 and 2000 were turned down by Vietnam (Storey 2001; Brewster 2009). The Vietnamese were no 
doubt concerned about its own relationship with China, and ASEAN states too would have likely seen such a development as unnecessarily provocative. A less provocative scenario for any credible extension of Indian naval power into the South China Sea might involve non-exclusive arrangements for the use of Singapore's Changi Naval Base, just as it is currently used by the United States navy. It has been reported that an arrangement allowing for "frequent visits" of Indian naval vessels to Changi Naval Base is already in place, and the development of an Indian logistical presence seems not beyond the realms of possibility (Mohan 2008b: 49).

\section{Regional perspectives on an Indian security role}

The views of Singapore's ASEAN partners towards the increasing security role of India in the region have generally been cautious, though not unwelcoming. Although concerns were expressed in Indonesia and Malaysia about the Indian naval buildup during the 1980s, India is now generally seen as a benign security presence.

Unsurprisingly, there are many different perceptions of India across ASEAN, ranging from Burma's suspicions of its large neighbor to Vietnam's longstanding political relationship with India. While Malaysia and Indonesia have often (at least, rhetorically) opposed the strategic intrusion of outside states into Southeast Asia, both these and others in the region are fully aware of China's increasing economic dominance of the region and growing military capacity (including the new Chinese Sanya Naval Base on Hainan Island), and as a result an Indian role in the region is generally viewed positively. Over the last decade or so, India has made an effort - with mixed success - to build security ties with Vietnam, its longstanding political ally in the region (Brewster 2009), as well as with Indonesia (Jha 2007) and Malaysia (Suryanarayana 2008). There are obstacles in development of these relationships, at least in the short term: for Vietnam the physical proximity to China creates major sensitivities and for Indonesia and Malaysia there is the Islamic factor as well as territorial sensitivities over the Malacca Strait. 
Despite general improvements in regional security relations, concerns also remain in the region about the potential for triggering a regional naval race between India and China and on the potential impact on the ability to build regional security institutions including China. There are also real questions about India's ability to act as a regional security provider, particularly if it is unable to create a stable security environment in its own region. As one commentator put it: "More than any power projection capabilities, ASEAN's main expectation vis-à-vis India in terms of security would be its capacity to ensure the stability of the subcontinent itself... India's aspirations to a political role in Southeast Asia would certainly be more credible if it was able to settle its dispute with Pakistan" (Grare 2001: 136). In addition, most East Asian states still regard India as an Indian Ocean and not a Pacific maritime power, and the credibility of Indian naval power in the region remains limited.

\section{Singapore perspectives}

As we have seen, Singapore has for many years consistently welcomed an increased security role for India in the region and has actively sought to encourage that role. This does not merely reflect a recent desire to use India to balance against China's rising power in what the Singapore Foreign Minister George Yeo has called Singapore's "strategic promiscuity," but also by a belief that India has a "natural" security role in the region.

Unlike larger Southeast Asian states that have often (at least publicly) resisted a security role for outside powers in the region, Singapore has consistently welcomed and encouraged a balanced role for external security providers on the basis that competition between major regional powers "must be squarely confronted and cannot be wished away."(Goh:2005) As Singapore's first and long-serving Foreign Minister, S.Rajaratnam, explained: "Where there is a multiplicity of suns, the gravitational pull of each is not only weakened but also by a judicious use of the pulls and counterpulls of gravitational forces, the minor planets have a greater freedom of navigation" (Kwa 2006: 7). Similarly, as the current Prime Minister Lee Hsien Loong has argued, Singapore's concept of a balance of power "depends on the competing interests of several big powers in the region, rather 
than on linking the nation's fortunes to one overbearing power. The big powers can keep one another in check, and will prevent any one of them from dominating the entire region, and so allow small states to survive in the interstices between them" (Straits Times, 6 November 1984). Leifer has characterized this policy as "a paradoxical combination of non-alignment and balance of power, with an emphasis on the latter." (Leifer 2000: 5-6).

In seeking such a balance, Singapore's founder, Lee Kuan Yew, was not unhappy to see the growth in Soviet naval capacity in the Indian Ocean in the early 1970s as a useful balancing force in the region (Latif 2006: 236), a position which only changed in 1972 following signing of the IndiaSoviet friendship treaty. In his first visit to Beijing in 1976, Lee also declared that the stronger China became, the better and more equal the balance between the United States, the Soviet Union and China. During the 1980s, Lee suggested that Japan should take a greater role in balancing Soviet and Chinese influence in the region. Historically however the Singaporeans have regarded the United States as the key benign hegemon, with a particular role in contributing to the region's security and, as a result, they have worked to facilitate a strong US security presence in the region. Beginning in the early 1990s when the US navy faced eviction from Subic Bay, Singapore sought to secure the presence of the US navy in the region through agreements permitting the establishment in Singapore of US naval logistics centre servicing the US Seventh Fleet and the use of Singapore by US aircraft (including allowing for the rotational deployment of US fighter aircraft).

Singapore's approach to India in part reflects this thinking. Singapore's regional sponsorship of India reflects a cardinal principle of its balance of power approach to international relations, which is that a regional order cannot be durable if it seeks to exclude an existing or emerging power. In predicating its foreign policy on encouraging all great powers to participate in the affairs of Southeast Asia, Singapore has worked on the basis that the powers must have a viable stake in the regional order for it to be sustainable (Latif 2006: 236). As the Singapore Foreign Minister Jayakumar stated in 2000: "What we can be certain [of] is the fact that Indian will play an 
important role in the new equilibrium that will emerge... India's strategic importance therefore cannot be over-emphasised" (Uniyal 2000). However, Singapore's encouragement of India's strategic engagement in the region is intended to create a positive balance and not to encourage rivalry between India and China. Singapore was reportedly uneasy about the way in which the Bush administration cultivated the India-US relationship in the context of its China policy, which was thought to add to regional uncertainties (Sridharan 2003: 30).

The development of the India-Singapore relationship has also taken place, and in some ways been facilitated by, the strategic rapprochement between India and the United States over this decade, and there are many issues on which there is a coincidence of interests between the three. However, any implication that there may be a trilateral coalition to contain China should be avoided, as each of Singapore, India and the United States have very different perspectives on China. ${ }^{15}$ While the power of China represents an obvious source of concern, Singapore's desire to encourage India to act as a security provider is not just intended to balance China but has the broader motivation of ensuring an overall balance of power in the region (which clearly includes balancing China but arguably also includes balancing Singapore's reliance on the United States and Japan). More immediately, a "special relationship" with India significantly improves Singapore's strategic power and political bargaining position vis a vis its large Muslim neighbours, Malaysia and Indonesia and, arguably, could also increase Singapore's attractiveness to the United States as a regional security partner.

Importantly, for Singapore India is seen not just as another external power. The Singaporeans see India as an essentially benign security partner, which unlike Japan or China, carries no adverse historical baggage in the region. Further, while others have not been entirely comfortable with claims about India's historical influence in the region, Singapore (perhaps due to their majority Chinese ethnic background) has been happy to acknowledge the extent of Indian cultural influence and have used it to distinguish themselves from Northeast Asians. As Singapore 
Foreign Minister George Yeo once commented: “... the influence of Indian civilization... has given to South-east Asian Society a certain gentleness which characterises the region and makes it so different from North-east Asia." (The Arts, November/ December 1995, p.4).

Moreover, there is also a geopolitical element underlying Singaporean thinking. India is not just another rising external power, but has a natural strategic role in Singapore and the rest of Southeast Asia that it strangely sought to deny for nearly half a century. As K.Kesavapany, a former senior Singaporean diplomat, put it: "India has de facto inherited the British security role" stretching from Aden to Singapore (Kesavapany 2006: 48). This approach reflects a belief that the East Asian and South Asian security "complexes" which operated since at least the end of World War II in an almost completely separate manner, are in the process of merging into a single security region. As George Yeo stated: “India's rise compels us to look at our environment in new ways. It will be increasingly less tenable to regard South Asia and East Asia as distinct strategic theatres operating only at the margins" (Yeo 2002).

There are also significant benefits to Singapore's armed forces from the development of close security relations with India. The availability of Indian facilities provides Singapore with much needed training areas and gives Singapore additional strategic depth, particularly for its air force and navy. The opportunity to train with forces deploying Soviet/Russian equipment and non-Western military doctrine also provides a significant tactical benefit to Singapore, particularly given the extent of Soviet/Russian equipment deployed by the Malaysian armed forces (and perhaps also given India's role in providing training to the Malaysian air force) (Ho 2008).

Singapore's motivations for security engagement with India can therefore be seen in somewhat different terms than India's developing security relationships with U.S. regional allies such as Japan, Australia and South Korea. To a significant extent the steps they have taken in developing security relationships with India have paralleled improvements in the U.S.-India strategic relationship. While this new strategic orientation has certainly assisted the India- Singapore 
relationship, Singapore has traditionally viewed India as a regional security provider independently of any U.S. alliance. As a result of this particular perspective, in a somewhat remarkable feat for such a small country, Singapore has led the way in drawing India into a security role in Southeast Asia.

\section{Indian perspectives}

The Indians have been much less clear and consistent in their thinking about security engagement with Singapore and with Southeast Asia in general. This reflects the often conflicting pressures faced by India. These include immediate security threats in South Asia, perceived encroachments of China into the Indian Ocean, concerns about China's increasing economic dominance in Southeast Asia, and an understandable desire to avoid being used by others to balance against China. The unwillingness (or inability) to fully articulate India's security policy in Southeast Asia also reflects the continuing evolution in Indian strategic thinking about the region from the traditional Nehruvian doctrine towards a strategic doctrine that includes balance of power and geopolitical thinking.

There are certainly indications that India is beginning to accept what in 2006 Indian Defence Minister Mukherjee called a "crucial" role in maintaining a "stable balance of power" in the region (Mukherjee 2006). There is however, significant sensitivity about any acceptance that India is necessarily balancing against China. Former Indian foreign secretary, Sudhir Devare, for example, warns against seeing India's relationships in Southeast Asia merely through the lens of "balancing" against China, stating: "India does not and should not seek closer military ties with Southeast Asia as a bulwark against China or Pakistan" and that such an approach would be "flawed conceptually as well as disastrous politically" (Devare 2006: 211). According to Mohan, despite the "exaggerated debate "about India's rivalry with China, New Delhi is acutely conscious of its limitations in Southeast Asia and therefore wish to expand India's strategic weight in the region while avoiding creating overt rivalry with China (Mohan 2008b: 53). 
Many in the Indian security community are increasingly taking more of a geopolitical approach to India's strategic horizons. This involves a recognition of the Indian Ocean as India's "natural" strategic space Although India's claims of interest over the northern Indian Ocean have been given several formulations, there appears to be a definite consistency in intent. In 2000, Defence Minister George Fernandes Official spoke of an extended Indian area of interest from "the north of the Arabian Sea to the South China Sea" (Aneja 2000). In 2001, the Ministry of Defence described India's security environment as extending from the Persian Gulf in the west, to the Straits of Malacca in the east (Indian Ministry of Defence 2001), an area which Foreign Minister Jaswant Singh later called India's sphere of influence (Times of India, 13 April 2001). This was reiterated by the current Prime Minister Manohman Singh who claimed in 2004 that the region "bounded by the Horn of Africa, West Asia... South-East Asia and beyond, to the far reaches of the Indian Ocean" constituted what he called India's strategic footprint (Singh 2004). The expansion of India's strategic space involving what has been called a new "Forward Policy" has not been without criticism with some Indian analysts seeing it as an inappropriate return to imperial thinking, when Britain represented the sole superpower in the region and the world (Subrahmanyam 1999). Nevertheless, it would not be difficult to characterize India's developing relationship with Singapore in such terms. The use of Singapore as an eastern "anchor" to India's strategic space can also be bracketed with some of India's developing security relationships to its west. Just as the small and strategically located Singapore represents a politically attractive and non-threatening security partner in Southeast Asia, India has also developed good security relationships with the Gulf States, particularly Oman, where the Indian navy has also taken the lead in developing a security presence (Hussain 2008). ${ }^{16}$ India has also developed a good security relationship with Israel, primarily based on technology and intelligence sharing, which has similarities to elements of India's relationship with Singapore. 
The Indian navy has certainly been particularly proactive in developing a security relationship with Singapore seemingly ahead of the Indian government's public position. This reflects the particular role which the navy sees for itself in developing India's strategic space in the Indian Ocean while its land-based colleagues are locked in to conflicts on India's western and northern borders. The Indian Ocean Naval Symposium organized by the Indian navy in February 2008 and modeled on the US-led Western Pacific Naval Symposium (and to which neither the United States nor China were invited) is just one indicator of the leading role that the Indian navy sees for itself in the region. However, the Indian navy's proactive "naval diplomacy" has not been without controversy, including among those who are concerned about the Indian navy potentially entangling India in foreign obligations or alliances. This can be seen in the political controversy surrounding the Indian navy's participation in the Malabar 2007 exercise with the United States, Japan, Australia and Singapore. There is also rumoured to be particular tension between the Indian navy and Ministry of External Affairs over the navy's regional policy, including over the navy's recent assertive role in antipiracy operations off Somalia.

The failure of India to provide clarity or transparency on security aspects of its Look East Policy does not appear to have prevented it from making significant steps towards engagement in the region. As C. Raja Mohan has observed:

"The end of the cold war and the efforts to globalise the economy put India willy-nilly on the path of a new forward policy. India never consciously articulated its approach in terms of theory that demanded activism in the neighbouring regions to enhance its own security. Its regional initiatives were presented in terms of mutual economic benefit and the restoration of historic links, but their strategic significance was unmistakable." (Mohan 2004: 209) Mohan has also suggested that India is unlikely to articulate a grand theory about its own position in the region given the lack of concern in the region about the rise of India. Having flirted disastrously with grand concepts in the past, India's emphasis is on cautious realpolitik (Mohan 2008: 12). Tellis 
also suggests that in the current strategic environment, India does not have the luxury of pursuing policies that are "utterly transparent or completely straightforward" and instead must develop the institutional and psychological capacity to move deftly (Tellis 2007: 129).

Despite these debates, India continues to be enthusiastic in using Singapore as its gateway into Southeast Asia and - to some extent - is content to allow itself to be used as a balancing power in the region. As Indian Defence Minister Pranab Mukherjee has stated, Singapore has become the hub of its political, economic and security strategy in the whole of East Asia (Mukherjee 2006). However, Singapore's size and limitations arising from its omnidirectional foreign policy means that India will continue to develop its relationships with other major states in the region, particularly Indonesia and Vietnam. Further, while the Indian navy has taken a leading role in developing the India-Singapore security relationship, one could still argue persuasively that India's relationship with Singapore is driven primarily by an imperative of economic integration with Southeast Asia and East Asia and that the political and security dimensions of regional relationships naturally follow that imperative. Whichever is the chicken or the egg, it seems inevitable and, as some would argue, natural, that India will find itself playing an important role as a security provider to Singapore and the region. Whether India has the political wherewithal to extend its strategic reach further into East Asia remains to be seen.

\section{Notes}

${ }^{1}$ Pannikar proposed that in the long term, independent India and Indonesia, as the local sea powers, would need to take joint responsibility for the security of Singapore.

${ }^{2}$ Lee Kuan Yew reports, for example, that the Indian diplomatic missions gave the newly-independent Singapore "unstinting assistance" in gaining acceptance into Afro-Asian organizations. 
${ }^{3}$ It has also been suggested that the Indians, then seeking to consolidate their position in Bhutan, believed that it may have unduly antagonized China. In 1967 India offered Singapore a token amount of military equipment (a training aircraft and horses) and limited training to Singapore naval personnel.

${ }^{4}$ The Malaysians also sought to persuade the Indians to join in the collective defense of Asia, proposing an "association" between India and Japan as the two major non-communist powers in Asia.

${ }^{5}$ As stated by the then Singapore Minister for Information (now Foreign Minister), George Yeo, while on a visit to India in 1993.

${ }^{6}$ Escalating tensions between Singapore and Malaysia over security-related issues from the late $1980 \mathrm{~s}$ included a large scale military exercise by Malaysia and Indonesia in the adjacent Malaysian state of Johor in August 1991, culminating on Singapore's National Independence day. Singapore responded with a large scale military mobilisation. Serious political tensions with Malaysia continued through the 1990s.

${ }^{7}$ Malaysia, Thailand and Philippines reportedly opposed it despite Singapore's energetic advocacy.

${ }^{8}$ Interestingly, Lee went further than the Indian proposal and suggested the inclusion also of Sri Lanka and Pakistan in such a grouping.

${ }^{9}$ For a comprehensive discussion of the negotiation and content of the CECA, see See Chak Mun, India's Strategic Interests in Southeast Asia and Singapore (Singapore: Institute of South Asian Studies, 2009)

10 Singapore is also reportedly the frontrunner in a major Indian order of lightweight howitzers that will dwarf previous Singapore's previous arms export orders. "India expected to buy Singapore howitzers" Asian Defence 12 March 2009. ${ }^{11}$ Something originally suggested by India to Singapore in November 1995.

${ }^{12}$ Singapore has or has had arrangements for the training of Singapore Armed Forces in Australia, Brunei, France, Indonesia, New Zealand, South Africa, Thailand, Taiwan and the United States. The Singapore Air Force operates permanent flight training establishments in the United States, Australia, Brunei and France.

${ }^{13}$ In a counterpoint to the arrangements with Singapore in 2006 India announced the establishment of an air base in Tajikistan.

${ }^{14}$ The presence of naval forces of non-littoral states in the Malacca Strait is complicated by fact that as the strait itself is largely within territorial waters, under international law foreign naval vessels have a right of transit only. 


\footnotetext{
${ }^{15}$ For a detailed discussion of the trilateral relationship and perspectives on China, see Latif, Three Sides in Search of a Triangle: Singapore-America-India Relations.

${ }^{16}$ As at December 2008 India was in the process of negotiating a security agreement with Oman which has been reportedly described by Indian officials as "just short of stationing troops."
}

\section{References}

Aneja, Atul (2000) "India, Vietnam partners in safeguarding sea lanes," The Hindu, 15 April.

The Arts, November/December 1995.

Bernama (2006) (Malaysian News Agency), 3 June.

Brecher, Michael (1968) India and World Politics: Krishna Menon's View of the World, London:

Oxford University Press.

Brewster, David (2009) “India's Strategic Partnership with Vietnam: The Search for a Diamond on the South China Sea?" Asian Security Vol.5, Issue 1, pp. 24-44.

Chew, Emrys (2008) "A Merlion at the Edge of the Afrasian Sea: Singapore's Strategic Involvement in the Indian Ocean" RSIS Working Paper No. 164.

Curzon of Kedleston, Lord (1909) The Place of India in the Empire, London: John Murray.

Devare, Sudhir (2006) India and Southeast Asia: Towards Security Convergence, Singapore: Institute of Southeast Asian Studies.

Dixit, J.N. (2004) Makers of India's Foreign Policy: Raja Ram Mohun Roy to Yashwant Sinha, New Delhi: HarperCollins.

Dutt, V.P. (1984) India's Foreign Policy, New Delhi: Vani Educational Books.

Goh Chok Tong (2005), “Constructing East Asia," Speech to Asia Society, 15th Asian Corporate Conference, Bangkok, 9 June. 
Grare, Frederick (2001) "In Search of a Role: India and the ASEAN Regional Forum" in Frederick Grare and Amitabh Mattoo (eds.), India and ASEAN: The Politics of India's Look East Policy, New Delhi: Centre de Sciences Humaines.

Ho, Weizan (2008), “Examining Singapore-India Security Relations after the Cold War: Motivating Factors, Trends and Implications for Singapore" (unpublished thesis, National University of Singapore, 2000).

Hussain, Zakir (2008), "Indian PM's visit to Oman and Qatar" IDSA Strategic Comments, 2 December. Huxley, Timothy (2000), Defending the Lion City (St Leonards: Allen \& Unwin). Indian Business Insight, 30 June 2005. Indian Ministry of Defence (2001), Ministry of Defence Annual Report 2000-2001. Indiapost (2008) "Singapore as a gateway for Indian companies," 23 June. (www.indiapost.com) Jane's Sentinel Southeast Asia (2008) Issue No.22. Jha, Pankaj K. (2007) “India-Indonesia: Emerging Strategic Confluence in the Indian Ocean Region” Strategic Analysis, Vol.32, No.3, pp.439-458. Joseph, "Navy Hails Successful South China Sea Visit" Rediff on the Net, 17 October 2000. Kesavapany,K. (2006) India's Tryst with Asia, New Delhi: Asian Institute of Transport Development. Khurana, Gurpreet S. (2008), "The Malacca Straits 'Conundrum' and India” in N.S.Sisodia and Sreeradha Datta (eds.), Changing Security Dynanics in Southeast Asia, New Delhi: Institute for Defence Studies and Analysis.

Kumar, Dr Nagesh (2006) "Regionalism with an 'Asian Face': An Agenda for the East Asia Summit" RIS Policy Briefs No.28, October.

Kwa, Chong Guan (2006), S Rajaratnam on Singapore: From Ideas to Reality, Hackensack, N.J.: World Scientific.

Latif, Asad-Ul Iqbal (2006) Between Rising Powers: China, Singapore and India, Singapore: ISEAS Publishing. 
(2009) Three Sides in Search of a Triangle: Singapore-America-India Relations,

Singapore: ISEAS Publishing.

Lee, Kuan Yew (2000) From Third World to First: The Singapore Story 1965-2000, Singapore:

Singapore Press Holdings.

(2005) “Lee Kuan Yew Reflects” Time Asia, 5 December.

Leifer, Michael (2000) Singapore's Foreign Policy: Coping with Vulnerability, London: Routledge.

Mahizhnan, Arun (1994) "Developing Singapore's External Economy," Southeast Asian Affairs Vol.21, pp.285-301.

Maitra, Ramtanu (2005), "India bids to rule the waves," Asia Times, 19 October.Mohan, C.Raja (2004) Crossing the Rubicon, New York: Palgrave Macmillan.

(2008a), "India's Changing Strategic Profile in East and Southeast Asia" (Paper

presented at the Regional Outlook Forum, Singapore, 8 January 2008).

(2008b), "India's Geopolitics and Southeast Asian Security" in Daljit Singh and Tin

Maung Maung (eds.), Southeast Asian Affairs 2008 (Singapore: Institute of Southeast Asian Studies, 2008).

- (2009), “Is India and East Asian Power? Explaining New Delhi's Security Policies in the

Western Pacific," ISAS Working Paper No.81, 11 August 2009.

Mukherjee, Pranab (2006) Address to the 5th IISS Asian Security Summit, 3 June.

Muni, S.D. (2003) “India and Singapore: Bilateral Issues,” in N.N.Vohra (ed.), Emerging Asia:

Challenges for India and Singapore (New Delhi: Manohar Publishers), pp.22-48.

Naidu, G.V.C. (2000) The Indian Navy and Southeast Asia, New Delhi: Knowledge World. (2004) "Whither the Look East Policy: India and Southeast Asia" Strategic Analysis,

Vol.28, No.2 (April-June 2004), pp.331-346.

Ong, Timothy (2004) “No Slowing Down,” Asia Inc, November. 
Panikkar, K.M., (1943) The Future of Southeast Asia: An Indian View, New York: The Macmillan Company.

Scott, David (2007) “India's Drive for a 'Blue Water' Navy” Journal of Military and Strategic Studies (Winter), Vol.10, Issue 2, pp.1-42.

Sengupta, Prasun K. (1998) “A Builder's Navy Takes Shape” Asian Defence Journal (October) pp.1621.

Singh, Bilveer (1999) The Vulnerability of Small States Revisited: A Study of Singapore's Post-Cold War Foreign Policy, Yogyakarta: Gadjah Mada University Press.

Singh, Manohman (2004) "PM's Address at the Combined Commander's Conference," 24 October. Sridharan, Kripa (1996) The ASEAN Region in India's Foreign Policy (Aldershot: Dartmouth Publishing).

(2001), "Regional Perceptions of India" in Frederick Grare and Amitabh Mattoo (eds.), India and ASEAN: The Politics of India's Look East Policy, New Delhi: Centre de Sciences Humaines, pp.67-89.

(2003) "Transcending the Region: Singapore's India Policy" in N.N.Vohra, Emerging Asia: Challenges for India and Singapore, New Delhi: Manohar, pp.15-32.

Statesman, 16 June 1980.

Straits Times, 3 September 1966. 6 November 1984. 20 January 2000. , 15 November 2000, p.17. 17 November 2005.

Storey, Ian and Carlyle A.Thayer (2001) "Cam Ranh Bay: Past Imperfect, Future Conditional," Contemporary Southeast Asia, Vol.23, No.3 (December), pp.452-73. 
Subrahmanyam, K. (1999) "Introduction" in Jaswant Singh, Defending India, New York: St. Martin's Press.

Suryanarayan, Dr.V. (2008) “India-Singapore Relations: An Over View” Chennai Centre for China Studies, C3S Paper No.140, 2 April.

Suryanarayana, P.S. (2005) “A Vision for Asia” Frontline, Vol.22 Issue 1, 1-14 January. (2008) “India, Malaysia step up defence ties" The Hindu, 8 January.

Tellis, Ashley J. (2007) "India in Asian Geopolitics" in Prakash Nanda (ed.), Rising India: Friends and Foes, New Delhi: Lancer.

Times of India, 13 April 2001.

Uniyal, Mahest. "India's Look East Policy hit pay dirt in Southeast Asia" Asia Times, 21 November 2000.

Yeo, George (2002) Speech to India Economic Summit 2002, New Delhi. (2005) Address to the Global Leadership Forum in Kuala Lumpur, 6 September. 